\title{
Hybridní hrozby - fenomén v oblasti válek 21. století
}

\author{
Alžběta Kartusová \\ Západočeská univerzita v Plzni, Fakulta právnická
}

\begin{abstract}
Anotace: Tento odborný článek popisuje novodobý druh bezpečnostních hrozeb, tzv. hybridní hrozby, a snaži se osvětlit nejen samotný pojem hybridní hrozba či hybridní válka, ale taktéž přibližit i $v$ minulosti několikrát využivané metody při jejich plánování a vedení. Dále pojednává o způsobech obrany proti připadným hybridním útokům, a to jak na mezinárodní, tak také na národní úrovni.
\end{abstract}

Klíčová slova: hybridní hrozba, hybridní válka, bezpečnost

\begin{abstract}
This article describes a new kind of security threats - hybrid threats - and aims to clarify not only the terms hybrid threat and hybrid warfare, but also examine the methods that are being used in relation to planning and engagement in such warfares. Furthermore, it suggests methods of protection against possible hybrid attacks both on international and national level.
\end{abstract}

Keywords: hybrid threat, hybrid warfare, security 


\section{Úvod}

Ohlédneme-li se zpět do minulého století a srovnáme-li ho se stoletím jednadvacátým, zjistíme, že byt’ se naše společnost nachází na vrcholu vyspělosti celosvětové úrovně a z historie se snad dokázala poučit, stále se potýkáme s celou řadou hrozeb a nejistot. Tyto hrozby mají ale novou tvář a zaměřují se na zcela odlišné cíle, které jsme si dosud jako společnost nedokázali zcela určitě představit. $V$ této souvislosti se setkáváme s pojmem „hybridní hrozba“ stále častěji, a to nejen z novinového, rozhlasového i televizního zpravodajství. Můžeme však toto, mohlo by se zdát, neurčité slovní spojení nějak bliže definovat?

\section{Pojem}

Pojem „hybridní válka“ je obtižné přesně definovat. Každý stát, at již přimo ten, který se s hybridními útoky potýká, či ten, který pouze přihliží, či je o nich pouze informován prostřednictvím zpravodajských služeb, nebo je dokonce cílem takového útoku, si tento pojem může vykládat podle svého vlastního přesvědčení, získaných informací či například pomocí legislativních předpisů.

V 21. století můžeme largo sensu hybridní válku označit jako kombinaci civilních a vojenských způsobů a prostředků, které jsou používány sloučenými způsoby k dosažení cíle a ukotvení postavení útočícího subjektu, destabilizaci jiného subjektu nebo šírení dezinformací. ${ }^{1}$ Pokud bychom chtěli tento pojem

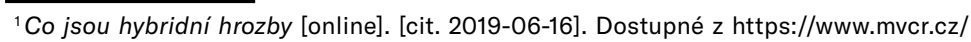
cthh/clanek/co-jsou-hybridni-hrozby.aspx 
představit $v$ užším slova smyslu, pak by se mohlo jednat o do detailu promyšlenou formu vedení dílčích útoků, at již na mezinárodní úrovni, kdy pozici útočníků a cílů hybridních válek zaujímají státy, či na dimenzi vnitrostátní, tedy na prolínání nestátního aktéra, který využivá konvenčních principů k narušení mírového fungování ve státě. Je nutno poznamenat, že pod hybridní hrozbu můžeme subsumovat útoky postavené na konvenčních vojenských silách, dále na nekonvenčních, ale také na těch, které celou problematiku posouvají od roviny taktické po rovinu politickou či ekonomickou.

Hybridním útokem Ize tedy nazvat radu dílčích kroků, kterými je vyvinut i nedestruktivní nátlak sledujíci poškození cíle útoku. Jde o dopodrobna promyšlené strategie, kterými se agresor pokouší narušit bezpečnostní, ekonomickou nebo politickou sféru, která je po desítky let budována, a donutí tak druhou stranu ke krokům, na základě kterých získá větší moc, výsadní postavení či jiný profit. K vysvětlení či upřesnění pojmu dochází neustále a existuje čím dále tím více názorů, co to vlastně hybridní hrozba je a jak ji definovat. Například podle Iva Zelinky (výkonný důstojník zástupce náčelníka Generálního štábu AČR) musí převažovat počet nevojenských prostředků nad těmi vojenskými. Nevojenským prostředkem jsou pak myšleny například kybernetické útoky, terorismus, využití polovojenských skupin či ekonomické nástroje jako sankce, embarga, kvóty.

At’ se přikloníme ke kterékoliv definici, která by mohla v pravém slova smyslu opravdu hybridni hrozbu definovat, měli bychom se možná zamyslet nad tím, proč je tato "moderni“ hrozba 21. století nazvaná právě jako „hybridní“. Znamená 
právě toto slovo hrozbu či válku z ní plynoucí jako „hrozbu“ méně závažnou, či naopak podstatnou?

\subsection{Př́klady z historie a současnosti}

Pojem hybridní hrozba začal být v dnešním slova smyslu využiván až zhruba od roku 2014, tedy po událostech, se kterými jsou tyto hrozby spojovány a hojně medializovány. ${ }^{2}$ Takovými mezníky, kde se hybridní hrozba a útoky skloňují snad ve všech pádech, může být například tzv. anexe Krymu či válka na východní Ukrajině.

Je možné dnes tedy hovořit o hybridní válce jako aktuálním problému, kterým si jako vyspělá civilizace procházíme? Definici hybridní hrozby, která je nastiňována, bychom rozhodně mohli doložit na několika historických událostech, jejichž průběh byl taktéž ovlivňován poskytováním neucelených, nepravdivých a někdy i nulových informací. $V$ posledních letech je poukazováno převážně na konflikty, ve kterých hlavní postavení zaujímá Rusko a USA. Strategie Ruska je hojně definována právě jako taková, která nástroje hybridních kampaní využívá. Takové chování však může vyplývat i z historického postavení Ruska, které se již od svých počátků připojilo ke strategii expanze, nebot čelilo neustálým útokům a ohrožení svého území. To, co je v nynějším postavení nové, vychází ze zkušenosti Ruska, přesněji z konfrontace s NATO, které sehrává nejen $v$ problematice hybridních hrozeb klíčovou roli

${ }^{2}$ KUBEŠA, Milan - SPIŠÁK, Ján. Hybridní hrozby a vývoj nové operační koncepce NATO [online]. 2011 [cit. 2019-07-03]. Dostupné z: https://www.obranaastrategie.cz/ cs/aktualni-cislo-2-2011/clanky/hybridni-hrozby-a-vyvoj-nove-operacni-koncepce-nato.html 
(viz níže). Proč se Rusko vydalo cestou skryté války, můžeme pouze polemizovat. Možná právě NATO, které samo o sobě má i své odpůrce a kritiky, představuje pomyslnou silovou hranici, přes kterou se Rusko neodhodlá vykročit, a je tedy nuceno dosahovat svých cílů pod prahem agrese, přesně tak, aby jeho snahy nebyly odkryty členskými státy NATO. Rusko na základě nesdílení stejných názorů s NATO považuje tuto alianci za neprátelsky laděnou, přestože je to právě Ruská federace, která je aktivní v kybernetické informační oblasti a má účinky $v$ ovlivňování nálad domácího i zahraničního obyvatelstva, týkajících se politiky či ekonomiky.

Aniž by byl pojem hybridní válka nebo hrozba jako způsob vedení války té nejmladší generace definován, byl poprvé masově použit v případě Ruska a anexe ukrajinského Krymu. Podle Ruska se však nejednalo o násilné ovládnutí ukrajinského území, ale mělo jít o převzetí mírové, které bylo iniciováno zespodu od obyvatel Krymu, nikoliv na základě vnějšího tlaku Ruska, přičemž tento postoj byl jako jediný intenzivně předkládán veřejnosti. Proč tedy byla využita ozbrojená intervence, kterou nezpochybnitelně zachytila světová média? $S$ názorem, že $v$ žádném připadě nešlo o mírové převzetí území, se ztotožnil mj. i Mezinárodní trestní soud v Haagu, který potvrdil, že vztah mezi Ruskem a ukrajinským Krymem byl mezinárodním ozbrojeným konfliktem. ${ }^{3} \mathrm{~V}$ této publikaci bychom dohledali názor a možná se $v$ něm i utvrdili, že

\footnotetext{
${ }^{3}$ Report on Preliminary Examination Activities 2018. The Office of the Prosecutor, International Criminal Court, odstavec 68 [online]. [cit. 2019-07-16]. Dostupné z: https:// www.icc-cpi.int/itemsDocuments/181205-rep-otp-PE-ENG.pdf. Působení Ruska je dle publikace HOFFMAN, Frank G., 2007a. Conflict in the 21st Century: The Rise of Hybrid Wars. Arlington, VA: Potomac Institute for Policy Studies, 72 s., novodobým typem vedení války.
} 
hybridní válka je velmi promyšleným postupem, který se skládá z několika klíčových fází od té první, která probíhá ve formě publikování dezinformací či využití diplomatických kroků, až po tu, ve které jsou využity samotné válečné zbraně. Tato poslední fáze představuje nejtěžší formu využití nástrojů využívaných jak při mezinárodních, tak také vnitrostátních konfliktech.

Zřejmě tím nejaktuálnějším př́ikladem, kdy Rusko bylo označeno jako strana využívající hybridní nástroje, je spojitost s posledními prezidentskými volbami v USA, kdy Rusko prostřednictvím mnoha falešných účtů a identit publikovalo množství informací, které měly za cíl rozdělit a popudit americkou společnost, a tím ovlivnit výsledky prezidentských voleb. Oficiální vyjádření Ruska vměšování se do vnitrostátních voleb USA dưrazně odmítala, což překvapivě nakonec tvrdila také americká vláda, když prohlásila, že k ovlivnění nedošlo a ani nebyly zaznamenány žádné útoky. Zda se ze strany Ruska jedná o úmysIné nepravdivé vyjádření a USA učinilo jen taktický krok, je jen těžko zjistitelné.

\section{Nástroje a způsoby využívané v hybridních válkách}

Nástroje, které mohou být využity při vedení hybridní války, můžeme spatřit již v mezinárodních konfliktech uskutečňovaných po celé století. Pokud se agresor rozhodne započít hybridní válku, respektive tzv. hybridní kampaň proti cíli svého útoku, využívá škálu nástrojů. Spektrum nástrojů, které jsou využívány a tvoři tak součást hybridní kampaně, nazýváme 
jako tzv. DIMEFIL (Diplomatic, Information, Military, Economic, Financial, Intelligence and Law Enforcement), díky kterým může mít agresorovo „válečné taženi““ mnoho podob. ${ }^{4} \mathrm{~V}$ rámci této problematiky je nutné pohližet na hybridní válku jako na široký rozsah nástrojů, které jsou využivány pro získání benefitů daného agresora. Mezi takové nástroje řadíme na prvním místě šírení (dez)informací nebo tzv. „fake news“, at” již pomocí sociálních sítí, nebo tradičních masmédií, které zapůsobí na značnou škálu obyvatel a s nimiž se setkáváme dennodenně. Právě tímto způsobem Ize relativně snadno docílit značného vlivu na mínění velkého počtu jedinců, například občanů konkrétního státu nebo členů organizace. Aktuálně primární informační kanály představují nejpopulárnější globální sociální sítě jako Twitter, Facebook či jiné lokálního rázu, ze kterých čerpáme nejrůznější zpravodajství. Cílovou skupinou jsou zde uživatelé těchto moderních sítí, kteři by si měli být vědomi faktu, že internet bude přinášet čím dál tím více informací, které však ne vždy budou podány pravdivě. Je tedy nejen na státním prvku uchránit své občany před dezinformacemi, ale taktéž na každém občanovi dokázat přijímané informaci porozumět, porovnat ji a až posléze vytvořit svůj vlastní pohled na danou problematiku, nebot může docházet $\mathrm{k}$ pokusu o zmatení daného jedince a utváření jeho neopodstatněného mínění.

Další oblastí, která je v rámci vedení hybridní kampaně ovlivňována a má neméně závažné důsledky, je samotná politika. Niccolo Machiavelli tvrdil: „V politice, kde není odvolacího soudu, soudí člověk podle výsledku.“ At dáme tomuto citátu

${ }^{4}$ Co jsou hybridni hrozby: O hybridních hrozbách [online]. [cit. 2019-07-03]. Dostupné z: https://www.mvcr.cz/cthh/clanek/co-jsou-hybridni-hrozby.aspx. 
za pravdu, či nikoliv, je právě politické dění jedním z nástrojů, který agresor využívá k ovlivňování celé společensko-politické nálady a vědomí občanů daného státu, ale i ke změně jejich politického přesvědčení a názoru na konkrétní problematiku.

Třetí oblastí, která je často cílem napadení hybridními útoky, je ekonomika. Na základě změn ekonomických prvků, kterými může být například zvýšení cla, zákaz dovozu či vývozu zboží, je daný cílový stát kontrolován a bezesporu je s ním jednáno tak, aby agresor tento státní celek koordinoval směrem dle svého uvážení a získal tím i právě „pouhou“ ekonomickou prosperitu, nebot' i ekonomický růst či ovlivnění ekonomického trhu na celosvětové i lokální úrovni může být bodem, kterého chce být dosaženo. ${ }^{5}$

K tomu, aby mohly být tyto kampaně efektivně využivány, jsou zapotřebí perfektní znalosti fungování a mezinárodního postavení daného cíle. $\mathrm{V}$ rámci rozvinuté hybridní války by tedy měly být využívány do detailu promyšlené kroky, které jsou vystavěny na dostatečném poznání úrovně zranitelnosti druhé strany, předvídání různorodých situací a výsledků (at̉ již z oblasti politiky, či taktéž zmíněné ekonomiky) a schopnosti flexibilně reagovat na aktuální bezpečnostní otázky například v kybernetickém prostoru, který se stále více rozrůstá a zrychluje tok informací do všech koutů světa.

${ }^{5}$ HOFFMAN, Frank G. Op. cit. sub. 4, str. 22. 


\section{Způsoby obrany proti hybridním útokům}

Již v minulosti se odehrálo několik klíčových mezníků, kdy si státy uvědomily nutnost mírových, mezinárodních, obchodních dohod, smluv a taktéž i organizací, které i nadále udržuji mezinárodní vztahy na přátelské bázi a soudržnosti. V posledních deseti letech kličovou roli sehrává Severoatlantická aliance založená roku 1949, známá spíše pod zkratkou NATO, která v boji proti hybridním útokům zastává zásadní postavení, i když má i své kritiky, odpůrce a je dokonce zpochybňována její činnost. Nelze ovšem přehlédnout, že to bylo právě NATO, které zařadilo pojem hybridní hrozba do širšího povědomí a dalo mu novodobý význam (byṫ ne přesnou definici). NATO a zástupci členských aliančních zemí, kteří se navzájem spojují a budují nové politické vztahy, reagují na případné hybridní útoky a navzájem kooperuji - předávaji si nové informace a zkušenosti s novým typem útoku.

Další širokou platformu spolupráce zaštituje Evropská unie, která si zakládá na spolupráci svých členů a tvoří tak nejdůležitějši prvek, na kterém je založena obrana proti hybridním útokům na země starého kontinentu. $V$ tomto roce Evropská rada prijala strategickou agendu pro rok 2019-2024, ve které se mj. zaměři i na problematiku dezinformací jako jednu z prioritních oblastí zasluhujíci si zvýšenou pozornost. Strategická agenda také předurčuje vyšší sankce, které by hrozily při využití kybernetického útoku třetího státu vưči členovi Unie. V roce 2016 byla prijata Globální strategie zahraniční a bezpečnostní politiky EU, která se na hybridní hrozby jako novodobý problém také zaměřuje. Píše se v ní kupř́kladu: „EU bude nadále prohlubovat partnerství s NATO prostřednictvím koordinovaného 
rozvoje obranných schopností, paralelních a synchronních cvičení a vzájemně se posilujících opatření k budování kapacit našich partnerů, proti hybridním a kybernetickým hrozbám..." Dále pak, že „... z bezpečnostního hlediska terorismus, hybridní hrozby a organizovaná kriminalita naznaji hranice. To vyžaduje užší institucionální vazby mezi naší vnější akcí a vnitřním prostorem svobody, bezpečnosti a práva“.

Jak bylo výše uvedeno, hybridní útoky zahrnuji i šíření dezinformací, ale i zcela nepravdivých skutečností, proto je nutné naučit každého jedince kritickému myšlení a schopnosti přijímané informace filtrovat a ověřovat důvěryhodnost těchto informací a jejich relevanci.

\section{4 Česká republika a hybridní hrozby}

Základní právní rámec obrany České republiky a zajištění její komplexní bezpečnosti poskytuje zejména ústavní zákon č. 110/1998 Sb., o bezpečnosti České republiky, zákon č. 222/1999 Sb., o zajištování obrany České republiky, zákon č. 240/2000 Sb., tzv. krizový zákon, zákon č. 219/1999 Sb., o ozbrojených silách České republiky, zákon č. 412/2005 Sb., o ochraně utajovaných informací a o bezpečnostní způsobilosti, a dále pak zákon č. 585/2004 Sb., o branné povinnosti a jejím zajištování (branný zákon), a zák. č. 153/1994 Sb., o zpravodajských službách.

Na národní úrovni došlo k vytvoření odborné složky specializující se na hybridní hrozby vůči České republice, a to Centrum proti terorismu a hybridním hrozbám (CTHH), které 
zahájilo svou činnost v lednu roku $2017 .^{6} \mathrm{~V}$ rámci své činnosti se CTHH aktivně zapojuje do zajímavých projektů na mezinárodní úrovni, některé dokonce pořádá ze své vlastní iniciativy. Činnost $\mathrm{CTHH}$ můžeme sledovat samozrejmě online, na jeho twitterovém účtu, kde bychom nalezli aktuality o jeho fungování a mnoha aktivitách. $V$ tomto roce například Centrum pořádalo Festival bezpečného internetu či se zapojilo do mezinárodní hry volně prístupné na internetu, která dle britského výzkumu po několika málo minutách aktivního hraní zlepšuje kritické myšlení a schopnost vytřídit tzv. "dezinfo“ až o $25 \%$. CTHH poskytuje informace o aktuálně šírených dezinformacích, které hojně kolují internetem, a pomáhá tak občanům v jejich rozlišování.

Problematikou hybridních hrozeb se zabývá v souladu s dodržováním Bezpečnostní strategie ČR z roku 2017, obsahující část týkající se hybridních hrozeb, jež v tomto dokumentu rozhodně nezastávají poslední místo k diskusi. Na tom je vidět, že i ČR jako stát stojící mimo okruh nejvýznamnějších globálních aktérů posiluje a nadále musí posilovat svou bezpečnost a odolnost vưči hybridním hrozbám a schopnost na ně dostatečně flexibilně reagovat, protože se mohou odehrávat i v rádu hodin a napáchat škody za miliardy. V současné době se ČR řadí mezi prvních deset nejbezpečnějších zemí z celého světa, o což musí nadále aktivně usilovat mj. proto, aby dokázala ochránit sdílené zpravodajské informace ze srovnatelně, nebo dokonce více zabezpečených zemí a nadále si tuto výměnu informací jako jeden z prostředků upevňování globální pozice udržet.

${ }^{6}$ Centrum proti terorismu a hybridním hrozbám [online]. [cit. 2019-07-03]. Dostupné z: https://www.mvcr.cz/cthh/clanek/centrum-proti-terorismu-a-hybridnim-hrozbam.aspx 
CTHH funguje pod záštitou Ministerstva vnitra ČR a jeho primárním úkolem je monitoring připadných bezpečnostních hrozeb, jejich řešení, rozpoznávání dezinformací, jejich uvádění na pravou míru a vyjadřování se k legislativě vztahující se $\mathrm{k}$ bezpečnosti našeho státu. O aktuálním bezpečnostním stavu České republiky pojednává Audit národní bezpečnosti ČR vydaný Ministerstvem vnitra ČR v roce 2016. ${ }^{7}$ Tento Audit se zabývá aktuální pružností legislativy zajištující bezpečnost našeho státu, možnou reakcí bezpečnostních složek na různorodou formu útoků, ale právě též na novodobé hrozby, kterým by Česká republika mohla čelit. Jedním z jeho závěrů je, aby Česká republika započala lepši koordinaci nejen uvnitř státu, ale posílila komunikační schopnost i vně. Je nutné si uvědomit, že byt je Česká republika relativně silným samostatným státem, je nutné spolupracovat na evropském poli, spolupracovat a třeba se i solidárně označit za stát dotčený hybridním útokem primárně vedeným proti jinému našemu spojenci z řad EU nebo NATO anebo alespoň vyjádřit nesouhlasný postoj s takovým aktem vůči kterémukoli jinému státu, př́padně poskytnout přiměřenou pomoc.

\section{Závěr}

Bez ohledu na definici pojmu je nutné, aby každý stát mohl dostatečně flexibilně reagovat na hybridní útoky ze strany jiných států a proti svým občanům.

${ }^{7}$ Audit národní bezpečnosti. 2016. Ministerstvo vnitra ČR, odbor bezpečnostní politiky a prevence kriminality. 
Legislativa je nutným základem, ovšem měla by pomoci zajistit, aby bezpečnostní složky mohly reagovat $v$ co nejkratším, ideálně reálném čase, kdy je obrana nejefektivnější a zároveň fakticky jedinou možnou, která je způsobilá útoku zabránit, odvrátit nebo alespoň minimalizovat škody, at už na národní úrovni, nebo v rámci mezinárodní spolupráce.

Velmi účinnou a levnou zbraní proti hybridním hrozbám je vzdělaná, sebevědomá a uvědomělá demokratická společnost, která je ochotna bránit demokratické hodnoty i svou národní identitu. Tato ochota zahrnuje mimo jiné splňování daňové povinnosti a zajištění dostatečného rozpočtu na obranu státu.

\section{POUŽITÉ PRAMENY}

Audit národní bezpečnosti. 2016. Ministerstvo vnitra ČR, odbor bezpečnostní politiky a prevence kriminality.

Co jsou hybridní hrozby [online]. Dostupné z: https://www. mvcr.cz/cthh/clanek/co-jsou-hybridni-hrozby.aspx

Centrum proti terorismu a hybridním hrozbám [online]. [cit. 2019-07-03]. Dostupné z: https://www.mvcr.cz/cthh/clanek/ centrum-proti-terorismu-a-hybridnim-hrozbam.aspx.

HOFFMAN, Frank G. Op. cit. sub. 4, str. 22.

KUBEŠA, Milan - SPIŠÁK, Ján. Hybridní hrozby a vývoj nové operační koncepce NATO [online]. 2011 [cit. 2019-07-03]. Dostupné z: https://www.obranaastrategie.cz/cs/aktualni -cislo-2-2011/clanky/hybridni-hrozby-a-vyvoj-nove-operacni -koncepce-nato.html 
Hybridní hrozby - fenomén v oblasti válek 21. století / Alžběta Kartusová

Report on Preliminary Examination Activities 2018 [online]. The Office of the Prosecutor, International Criminal Court, odstavec 68. [cit. 2019-07-16]. Dostupné z: https://www. icc-cpi.int/itemsDocuments/181205-rep-otp-PE-ENG. pdf. Působení Ruska je dle publikace HOFFMAN, Frank G. 2007a. Conflict in the 21st Century: The Rise of Hybrid Wars. Arlington, VA: Potomac Institute for Policy Studies, 72 s., novodobým typem vedení. 